Prepared for the U.S. Department of Energy

under Contract DE-AC05-76RL01830

\title{
Ancient Glass: A literature search and its role in waste management
}

Denis M. Strachan

Eric M. Pierce

July 2010

Pacific Northwest

NATIONAL LABORATORY

Proudly Operated by Battelle Since 1965 


\title{
DISCLAIMER
}

This report was prepared as an account of work sponsored by an agency of the United States Government. Neither the United States Government nor any agency thereof, nor Battelle Memorial Institute, nor any of their employees, makes any warranty, express or implied, or assumes any legal liability or responsibility for the accuracy, completeness, or usefulness of any information, apparatus, product, or process disclosed, or represents that its use would not infringe privately owned rights. Reference herein to any specific commercial product, process, or service by trade name, trademark, manufacturer, or otherwise does not necessarily constitute or imply its endorsement, recommendation, or favoring by the United States Government or any agency thereof, or Battelle Memorial Institute. The views and opinions of authors expressed herein do not necessarily state or reflect those of the United States Government or any agency thereof.

\author{
PACIFIC NORTHWEST NATIONAL LABORATORY \\ operated by \\ BATTELLE \\ for the \\ UNITED STATES DEPARTMENT OF ENERGY \\ under Contract DE-AC05-76RL01830
}

Printed in the United States of America
Available to DOE and DOE contractors from the Office of Scientific and Technical Information,
P.O. Box 62, Oak Ridge, TN 37831-0062;
ph: (865) 576-8401
fax: $(865)$ 576-5728
email: reports@adonis.osti.gov

\begin{abstract}
Available to the public from the National Technical Information Service, U.S. Department of Commerce, 5285 Port Royal Rd., Springfield, VA 22161 ph: (800) 553-6847 fax: $(703) 605-6900$ email: orders@ntis.fedworld.gov online ordering: http://www.ntis.gov/ordering.htm
\end{abstract}

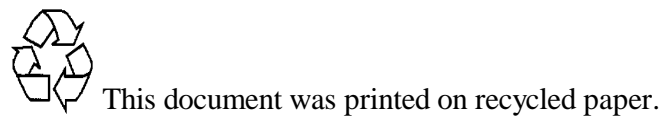




\section{Ancient Glass: A literature search and its role in waste management}

Denis M. Strachan

Eric M. Pierce

July 2010

Prepared for

the U.S. Department of Energy

under Contract DE-AC05-76RL01830

Pacific Northwest National Laboratory

Richland, Washington 99352 


\section{Summary}

A search of the literature was performed to find studies applicable to the validation of the long-term performance of nuclear waste glasses. Literature on both "ancient" and naturally-occurring glasses is shown. The term "ancient glass" is used here to denote both natural analogues, such as basalt glasses, obsidians, etc, and manmade glasses. The latter have a history dating back to about 3600 years ago or 1600 before the current era (bce). The former have ages that are $10^{6}$ years or older. In this document, I use both natural analogues and manmade glasses. 


\section{Acknowledgments}

I wish to thank Dr. Alberta Silvestri, University of Padova, and Dr. Russell Hand, University of Sheffield, for their time and efforts to support a recent trip to work with them and supported through a different project. Their many helpful discussions ultimately improved this document by providing insights from an archaeological point of view. I also wish to acknowledge the financial support from Washington River Protection Solutions, LLC. 


\section{Acronyms and Abbreviations}

$\begin{array}{ll}\text { bce } & \text { Before the current era } \\ \text { CEA } & \text { Commissariat à l'Énergie Atomique } \\ \text { GRAAL } & \text { Glass Reactivity with Allowance for the Alteration } \\ & \text { Layer } \\ \mathrm{kJ} / \mathrm{mol} & \text { Kilojoules per mole } \\ \mathrm{PNNL} & \text { Pacific Northwest Laboratory } \\ \mathrm{ppm} & \text { Parts per million }\end{array}$




\section{Contents}

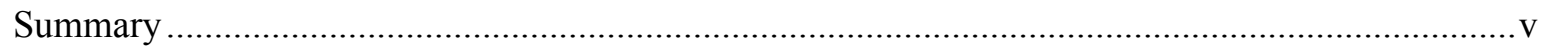

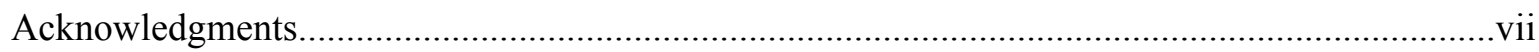

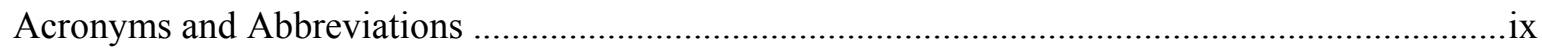

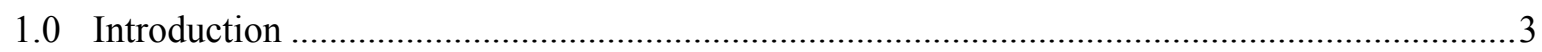

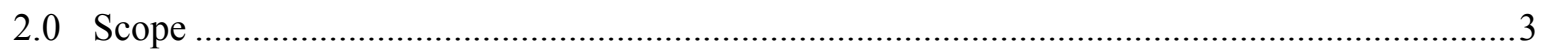

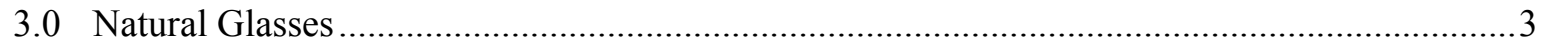

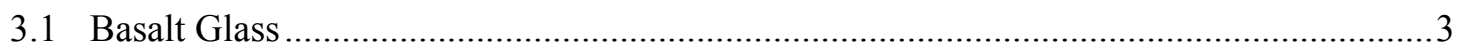

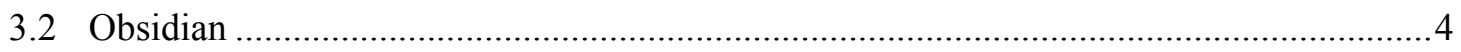

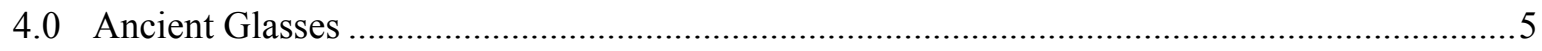

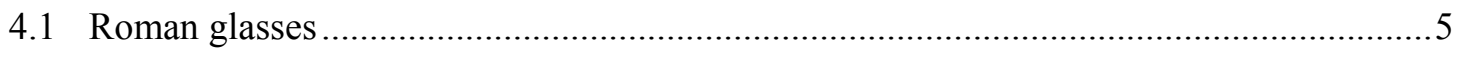

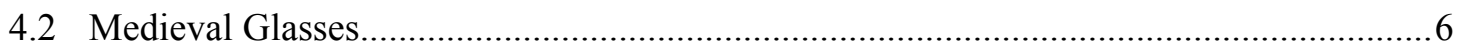

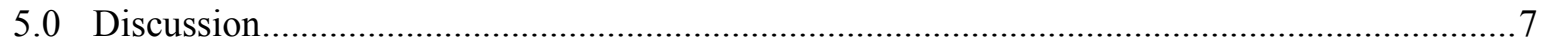

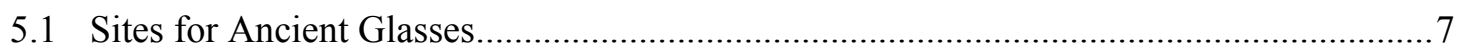

5.2 Needs for Repository Performance Assessment .......................................................... 8

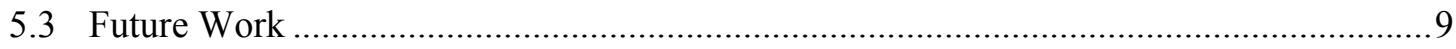

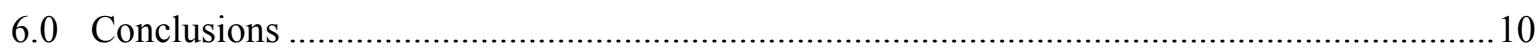

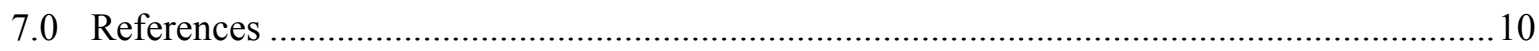




\section{Figures}

Figure 1. Pictures of Archaeologists Recovering a 200 ce House and the Techniques in Use.........9

Figure 2. A Typical Glass Artifact (circle; approximately $10 \mathrm{~mm} \times 15 \mathrm{~mm}$ ) at the Roman House..9 


\section{Introduction}

The term "ancient glass" is used here to denote both natural analogues, such as basalt glasses, obsidians, etc, and manmade glasses. The latter have a history dating back to about 3600 years ago or 1600 before the current era (bce). The former have ages that are $10^{6}$ years or older. In this document, I use both natural analogues and manmade glasses.

There are many uncertainties associated with the use of natural and manmade analogues to help resolve the dissolution mechanism of glass in water (Ewing and Roed 1987). Natural analogues perhaps have the most uncertainty, especially for the older glasses that formed in prehistoric times. The details of the conditions, even over many thousands of years, under which they were altered, are usually unknown. While some of the details for manmade analogues are also unknown, their recent history (ca $3600 \mathrm{y}$ ) relative to man (ca $2 \mathrm{My}$ ) make these uncertainties smaller. And in cases of sea burial, the number of uncertainties is reduced even more.

\subsection{Scope}

There are many studies of ancient and natural glasses. In this document, I will limit my discussion to those reports in the literature in which results from 'dissolution' experiments are reported. By dissolution experiments, I mean experiments in which actual or reproduced glasses were tested and the reaction with water reported. Because of the rarity and historical relevance of manmade glasses, few are destructively tested; most tests are performed on glasses of the same bulk composition, but made in the laboratory. There are some field results from studies of natural glasses that are relevant and those are also discussed. For example, one of the results from nuclear waste glass testing is the effect on the dissolution rate when the zeolite analcime [ideally $\mathrm{Na}\left(\mathrm{AlSi}_{2} \mathrm{O}_{6}\right) \cdot \mathrm{H}_{2} \mathrm{O}$ ] forms. There are some studies of zeolitization of natural glasses that could shed light on this effect.

\subsection{Natural Glasses}

Natural glasses can be divided into two basalt glass and rhyolitic glass or obsidian.

\subsection{Basalt Glass}

As with the industrial process for making glass, basalt glasses typically result from the rapid cooling of lava. This occurs mostly where basaltic lava flows into the sea, e.g. Hawaii and Iceland, or beneath the sea. Basalts are typically low in $\mathrm{SiO}_{2}$ (ca 50 mass\%) and alkali (2 to 4 mass\%) and high in the alkaline earth oxides $\mathrm{CaO}$ and $\mathrm{MgO}$. With respect to the $\mathrm{SiO}_{2}$ content, they are like the typical nuclear waste glass, but unlike most nuclear waste glasses, they are low in alkali and high in alkaline earth elements.

Alteration of these glasses in the low temperatures of the oceans leads to similar reaction products as those seen in laboratory experiments with simulated nuclear waste glasses. Basalt glasses found in the seas and subsurface are altered first by ion exchange then the formation of palagonite, an amorphous gellike alteration product that contains Fe and Al oxyhydroxides (Kruber, Thorseth, and Pedersen 2008; Crovisier, Advocat, and Dussossoy 2003). Crovisier, Advocat, and Dussossoy (2003) make two points 
with respect to basalt glass. The glass alters to palagonite in young $(<1 \mathrm{My})$ basalts and zeolites in old $(>$ $1 \mathrm{My}$ ) basalts. They also measured the activation energy for natural and synthetic basalt glass and SON68 (aka R7T7) and found it to be the same within experimental error for all three, suggesting that the dissolution mechanism was the same for all three (Crovisier, Advocat, and Dussossoy 2003). This can be construed as implying that a nuclear waste glass like SON68 would be appropriate for the disposal of nuclear waste as it would control the release of radionuclides to very low levels. One conclusion that was not reached or at least not mentioned by the authors is that when zeolites form on the glass, the glass does not necessarily completely dissolve. There are or could be mitigating environmental factors that could also cause the glass to survive the precipitation of zeolites.

Ghiara and coworkers (1993) performed experiments in a closed system at $200^{\circ} \mathrm{C}$ with basalt glass in demineralized and natural sea waters. In demineralized water, they found that the dissolution behavior was parabolic and that phillipsite, $\mathrm{Mg}$-smectite and analcime were the alteration products; grain size played no role in the formation of these alteration products. In sea water, the $\mathrm{pH}$ values remain acidic, thereby changing the identity of the alteration products to $\mathrm{Mg}$-smectite and anhydrite $\left(\mathrm{CaSO}_{4}\right)$; again no role was played by the grain size of the glass. Although not mentioned by the authors, there is again no indication that the presence of zeolites, especially analcime, had a deleterious effect on the overall dissolution of the glass.

Techer and coworkers (2001) studied the dissolution of a simulated basalt glass to which 1.0 mass \% (2.2 $\mathrm{mol} \%$ ) $\mathrm{Li}_{2} \mathrm{O}$ was added so that the reaction could be followed. For static tests at $90^{\circ} \mathrm{C}$, they observed

that the dissolution rate decreased by four orders of magnitude from the initial dissolution rate. The initial dissolution rate was similar to SON68. Upon testing the glass in a flow-through system both with demineralized water and silica saturated water $\left(\left[\mathrm{Si}_{\text {total }}\right]=130 \mathrm{ppm}\right)$, the maximum decrease in the rate was about 200. They attributed the disparity between the observed rates in the static and open system tests to the evolution of a dense layer that acted as a diffusion barrier to further dissolution under static conditions. Similarly, comparison of their results to the observed dissolution of many basalt glasses in nature led them to conclude that the dissolution rate, as measured from the thickness of the palagonite layer on the surface, was controlled by the diffusion of reaction products through the palagonite. They were silent on the question if all species were diffusion controlled or only specific species. In their concluding sentence, however, they mention only $\mathrm{H}_{2} \mathrm{O}, \mathrm{Na}^{+}$, and $\mathrm{H}_{4} \mathrm{SiO}_{4}$. Grambow and Strachan (1984) concluded from their experiments that the diffusion of the sole rate limiting species could control the dissolution of the underlying glass matrix.

Bajpai and coworkers (Bajpai and Narayan 2005; Bajpai, Narayan, and Trivedi 2006; Karkhanis, Bajpai, and Narayan 2006; Shrivastava, Bajpai, and Rani 2008) have examined basalt glasses as natural analogues for the disposal of nuclear waste glasses in India. These studies included results from experiments with basalt glasses both simulated and natural.

\subsection{Obsidian}

There are many studies of the dissolution of obsidian glasses. Three relevant ones are those by Anovitz and coworkers (Anovitz, Cole, and Fayek 2008; Anovitz, Cole, and Riciputi 2009; Anovitz et al. 2006). While the emphasis in these works is the role of obsidian dissolution to the mineral load of the nearby streams, the work is tangentially related to nuclear waste glass dissolution. 


\subsection{Tektites}

Although there are some early theories on the origin of tektites, the currently accepted one is that they result from the impact of a meteorite on the earth (O'Keefe 1986). This impact causes the soil and rock locally to melt, some of which is ejected from the impact site. The distance traveled by these ejecta is 100 $\mathrm{km}$ or more. It is suspected that to travel that far, they must certainly have traveled into space, but at less than escape velocities. Thus, the tektites are of terrestrial origin and this has been supported by isotope measurements. Tektites are relatively high in $\mathrm{SiO}_{2}$ averaging about 75 mass\% and they typically contain significant iron. Because of the high $\mathrm{SiO}_{2}$ concentration, tektites are rather durable.

Some of the early work on the weathering of tektites was done by (Lamarche, Lanford, and Rauch 1980). The work since that time has to do with the characterization of the weathering products (Marini et al. 2000; Papelis et al. 2003). Work specific to nuclear waste was carried out by (A. Barkatt et al. 1984; Mazer, Bates, Bradley, et al. 1992; A. Barkatt et al. 1994; A. Barkatt et al. 1989; Mazer, Bates, Stevenson, et al. 1992). Diffusion of water in tektites was measured by Mazer and coworkers (1992; 1992). The experiments were carried out like a vapor hydration test (J.K. Bates, Jardine, and Steindler 1982; J. K. Bates and Steindler 1983; Jiřička et al. 2001; Schatz et al. 2003). Although the amount of glass affected was very small $(<1 \mu \mathrm{m})$, the tektite altered to kaolinite (Mazer, Bates, Bradley, et al. 1992; J. K. Bates et al. 1991; Mazer, Bates, Stevenson, et al. 1992). Diffusion was identified as the ratecontrolling mechanism with an activation energy of $80-90 \mathrm{~kJ} / \mathrm{mol}$.

Barkatt and coworkers also studied tektites with the aim of understanding the long-term behavior of glass in the environment (A. Barkatt et al. 1989; Aa. Barkatt et al. 1986; A. Barkatt et al. 1984; A. Barkatt et al. 1994). These experiments were more classical in that they were dissolution tests with excess water. Dissolution rates were compared with the observed alteration of tektites in the environment. They found the alteration rates to be similar and similar to the dissolution rate determine with the free energy of hydration (C. M. Jantzen 1992; C.M Jantzen and Plodinec 1984; M. J. Plodinec, C. M. Jantzen, and G. G. Wicks 1984; M.J. Plodinec, C.M. Jantzen, and G.G. Wicks 1984).

Since the early 1990s, no additional work with tektites as the results relate to nuclear waste glasses has been done. The measurement of diffusion in these glasses in essentially a vapor hydration test yields results that are affected by reaction of the glass with water to form alteration products. Thus, the activation energies measured are not just for the diffusion process and, therefore, should be used with great caution.

\subsection{Ancient Glasses}

\subsection{Roman glasses}

The most recent work with Roman glasses is that by the French group (A. Verney-Carron, Gin, and Libourel 2007; A. Verney-Carron et al. 2009; Aurélie Verney-Carron et al. 2010; Aurelie Verney-Carron, Gin, and Libourel 2008; Frugier et al. 2009; Frugier et al. 2008) and the group at the University of Padova, Italy (Longinelli et al. 2004; Salviulo et al. 2004; Silvestri 2008; Silvestri, Longinelli, and Molin 2010; Silvestri, Molin, and Salviulo 2005a; Silvestri, Molin, and Salviulo 2005b; Silvestri, Molin, and Salviulo 2008; Silvestri et al. 2006; Benedetti et al. 2007; Dal Bianco and Bertoncello 2008; Dal Bianco 
et al. 2004; Dal Bianco et al. 2005). The French group worked with a glass block that was found in shipwreck in the Mediterranean Sea off the coast of France. The glass had been at the bottom of the sea for about $1800 \mathrm{y}$. Verney-Carron and coworkers (2010) used results from the characterization of the alteration layers in the cracks of this glass block and from experiments performed with both the actual unaltered glass and simulated glass to show that the dissolution was controlled by diffusion. They calculated the layer thicknesses and solution concentrations from their experiments with the GRAAL model (Frugier et al. 2009; Frugier et al. 2008). To explain the dissolution rate in this and nuclear waste glasses, a diffusion layer approximately $10 \mathrm{~nm}$ thick with a diffusion coefficient of $10^{-21} \mathrm{~m}^{2} \cdot \mathrm{s}^{-1}$ is used to describe a water diffusion barrier called the passivating reactive interphase.

The group at the University of Padova has done extensive studies of glass cullet found in the Iulia Felix shipwreck found at a depth of about $15 \mathrm{~m}$ about $10 \mathrm{~km}$ off the coast of Italy near the present town of Grado. This ship was carrying glass cullet to a glass melter, probably located in or near the town Aquileia. While no melter has been found, there is plenty of circumstantial evidence for the melter. The glass cullet was in a large barrel on the foredeck of the ship. The total mass of the material comprised about $140 \mathrm{~kg}$ and nearly 12000 pieces, most of which was colored glass (Toniolo 2008). The layers on these glass pieces have been very well characterized and reported in the references above. These glass pieces were under the sea for nearly 1800 y before being discovered by a fisherman. They were covered over by sea sediment after some undetermined period of time. The sediment in this part of the Adriatic is a mixture of calcite $\left[\mathrm{CaCO}_{3}\right]$, dolomite $\left[(\mathrm{CaMg})\left(\mathrm{CO}_{3}\right)_{2}\right]$, and minor pyrite $(\mathrm{FeS})$. Thus, while reducing, it contains no silica. Despite the similarity of the compositions of these glasses (Silvestri 2008; Silvestri, Molin, and Salviulo 2008), the layers on the surface of these glasses are different for the colored and colorless glasses with a multilayer sequence of lamellae on the colored glasses and a white amorphous layer on the colorless glasses (Silvestri, Molin, and Salviulo 2005a). It is unclear why these differences in dissolution occurred. No studies of the dissolution of these glasses has been undertaken.

\subsection{Medieval Glasses}

As with other ancient glasses, there has been much characterization of the glasses and their reaction products, but few studies have involved the testing of the actual or simulated glass. One of the only studies in which simulated medieval glasses have been tested has been carried out by Hannelore Römich and coworkers (Carmona et al. 2005; Fuchs et al. 1991; Mees et al. 2009; Römich 1999; Römich 2000; Römich 2003; Römich 2004; Römich 2006; Römich 2007; Römich et al. 2003). She studied medieval stained glass windows from German and English cathedrals. Remnants and fragments of these windows are often found buried on the church site. Therefore, her experiments were set up to mimic that burial environment. She used simulated glasses; glasses of the same composition made in the laboratory. The $\mathrm{pH}$ of the soil solutions was artificially adjusted with chemical solutions; the same soil was used in both test beds. For the more complex glass (9 components ( 48 mass $\% \mathrm{SiO}_{2}, \sim 3$ mass $\% \mathrm{Na}_{2} \mathrm{O}, \sim 24$ mass $\%$ $\mathrm{K}_{2} \mathrm{O}$, and others), she found that the glass developed etch pits in mildly acidic conditions $(\mathrm{pH}=6.5-7.5)$ whereas more or less uniform corrosion was found under more alkaline conditions $(\mathrm{pH}=8-9)$ (Römich et al. 2003). The glasses developed reaction rinds reminiscent of those found on artifacts. She states that Roman glasses, those with a sodium-lime-silica composition, are far more durable than those made after the collapse of the Roman Empire and were potassium-lime-silica compositions. 


\subsection{Discussion}

Results from the literature search shown above suggest few laboratory studies have been carried out with ancient man-made glasses (medieval and older) to determine if rates of dissolution and similarities with modern glasses for the disposal of nuclear wastes. Below I discuss the sites at which glasses have or might be found and what studies are needed to bring into focus the relevance between the result from the experiments that ancient man unwittingly started and the needs for present-day repository performance assessments.

\subsection{Sites for Ancient Glasses}

Strachan (2009) investigated various archaeological sites at which glasses might be found for use in verification of the performance assessment of the Hanford Site Integrated Disposal Facility. He identified four sites, Tell Ahmar, Tell Brak, Caesarea Maritima, and Khirbet Cana; the first two are located in Syria, the second two in Israel. His assumption was that the land-based sites offered the best possibility of obtaining data to support a verification effort. He also was looking for sites at which glasses could be found that approached the oldest available. Glass appears to have been 'discovered' about 4500 years ago in Egypt (Jackson and references therein). Extensive trade throughout the ancient world had much of this glass being transported as far away as Mesopotamia (Jackson). These conclusions were reached early by researchers such as Brill (1999), but the debate continued for a number of years because, while the major and minor components of the glasses from the Bronze Age glasses suggested Egypt, Mesopotamia could not be ruled out. The recent work by Jackson (2010) appears to have settled this debate. She used the trace elements in the glass blocks found in the Uluburun shipwreck off the coast of Turkey to show that the production site had to be Egypt, although only a very limited number of the glass ingots was analyzed. It is the existence of these glass ingots from the Uluburun that suggested glasses buried under the sea should not be ruled out for possible use to verify performance assessment codes.

Therefore, included with the land-based sites discussed earlier by Strachan (2009), three sea-based sites should be included - the site from which the French group obtained specimens, the Iulia Felix site, and the Uluburun site (G.F. Bass, "Oldest Known Shipwreck Reveals Splendors of the Bronze Age," National Geographic Magazine 172 no. 6 (December 1987), 692-733). While these are sites where glass has been found, they are still potentially useful for performance assessment verification. This is mainly because at no site has the profile of elements from the glasses buried there been measured and compared with the calculations of that profile. In the case of the Iulia Felix, the 'sand' does not contain silica. This means that there is an excellent chance that elements from the glasses could be tracked in the consolidated and cemented sediment. The fact that the sediment surrounding the glass artifacts is cemented by the growth of secondary calcite (Silvestri, Molin, and Salviulo 2005a) suggests that the dissolution of the glass caused this cementation; the normal sediment would not be expected to be and generally is not cemented. Fortunately, some of this cemented sediment exists and is part of an ongoing study by the University of Padova group. Most of the cargo on the Iulia Felix was ceramic jars. It would be useful to determine if any sediment from these artifacts exists. This site is closed and all artifacts are in storage.

Likewise, the other two sites are closed. It is unknown if there is any cemented sediment from these sites. An inquiry should result in an answer to this question. Other sites are likely to be found. If there is glass located at these new sites remains a discovery to be made. However, by working early with 
archaeologists, we can be in a position once glass artifacts are found to recover what is useful to us and not necessarily to the archaeologist.

\subsection{Needs for Repository Performance Assessment}

From a performance assessment point of view, the needs are both simple and complex. The simple fact is that the dissolution mechanism of the glass and a profile of dissolved elements in the environment are needed. If the dissolution mechanism and the transport mechanisms are known, then the calculation of both the release and the profile of released elements can be calculated. For archaeological glasses, this has never been done. One example of the calculation of the elemental profile from a man-made artifact was done on an ancient Greek bronze piece (Murphy article). This attempt was partially successful. Difficulties with the analysis of the soils made the comparison difficult and the instrumentation available at the time was much less sensitive than that currently available.

It is important to understand the relationship between archaeological glasses and the needs for performance assessment verification. As indicated, to calculate the dissolution of a nuclear waste glass in a repository, the mechanism by which glass and water interact must be know sufficiently well that the uncertainties are manageable. In the case of the current understanding of glass dissolution, there are four parameters for which values are needed. The uncertainties in these values propagate to the uncertainty in the dissolution rate at any given time and environmental chemistry. Secondly, the transport of these release radionuclides in the environment needs to be calculated so that the dose to an individual at the distance from the repository specified in the regulations can be calculated. This means that the chemistry of the radionuclide-rock interactions needs to be adequately determined. As with the release, the transport parameters become important to the calculation of the overall uncertainty in the dose to the individual. So it is with the archaeological glass. To calculate the profile of the released elements from the archaeological glass, both the release mechanism parameters and the interaction of these elements with the soil in which the artifact was buried need to be known and the uncertainties defined.

Archaeological glass analyses help provide a better understanding of the long-term dissolution of glass because the length of time this experiment has been carried out far exceeds any done in the laboratory. Thus, if certain phenomena, such as diffusion, have been operating, the expected effects should be very well manifest. Understanding and being able to calculate the effects of similar glasses in different environments, such as burial under the sea and different soil conditions (Silvestri, Molin, and Salviulo 2005a) leads to verification of the glass dissolution model, irrespective of the fact that no radionuclides exist in ancient glasses. Likewise, calculation of the profile of elements released from the glass allows the verification of the transport mechanism parameters and model, irrespective of the fact that no radionuclides exist in ancient glasses. 


\subsection{Future Work}

All sites have one common trait, glass is not necessarily to be found at these sites. When glass is found, the archaeologist scrapes away the interesting material (from our current perspective) and conserves the glass artifact. This means that there needs to be a good and a long-standing relationship between us and several archaeologists. At a recent visit to a site in Aquileia, Italy, it seemed improbable that a glass artifact would be found that could be used for performance assessment verification. This is because the archaeologist uses picks and shovels and scrapes vigorously at the soil with a sharp trowel and usually dislodges a glass specimen before noticing it as glass (Figure 1). Some of the initial excavation is done with a backhoe. After two days of being aware of the need for a glass specimen in a certain orientation, several were found; an example of one is shown in Figure 2. Depending on the site, glass artifacts, like dishes, cups, and plates, are rare finds; pieces of broken glass, like the piece shown in Figure 2 , which appears to be the bottom of a glass plate or some other piece with a decoration on it, are more frequently found.

Work on the glasses found both at the Iulia Felix site and Aquileia are continuing at the University of Padova. It is strongly recommended that collaboration between PNNL staff and the scientists at the University continue. Additional contacts also need to be cultivated.

Development of analytical methods is also needed so that we are in a position to analyze the glass artifacts and the surrounding soil. To date, there is no good method for consolidating the soil surrounding a glass artifact. One is in the formative stages at the University of Padova, but no complete method

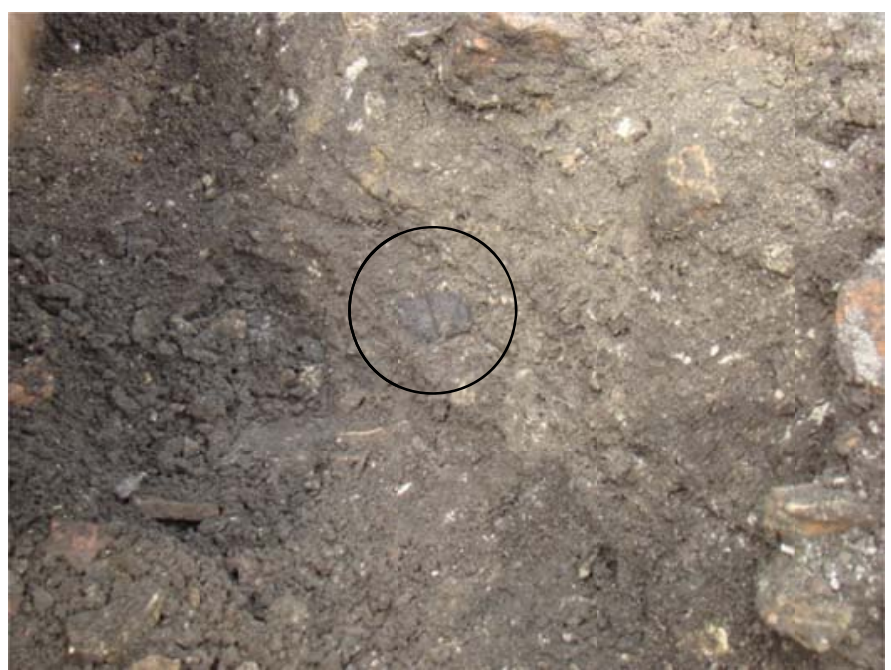

Figure 2. A Typical Glass Artifact (circle; approximately $10 \mathrm{~mm} \times 15 \mathrm{~mm}$ ) at the Roman House.
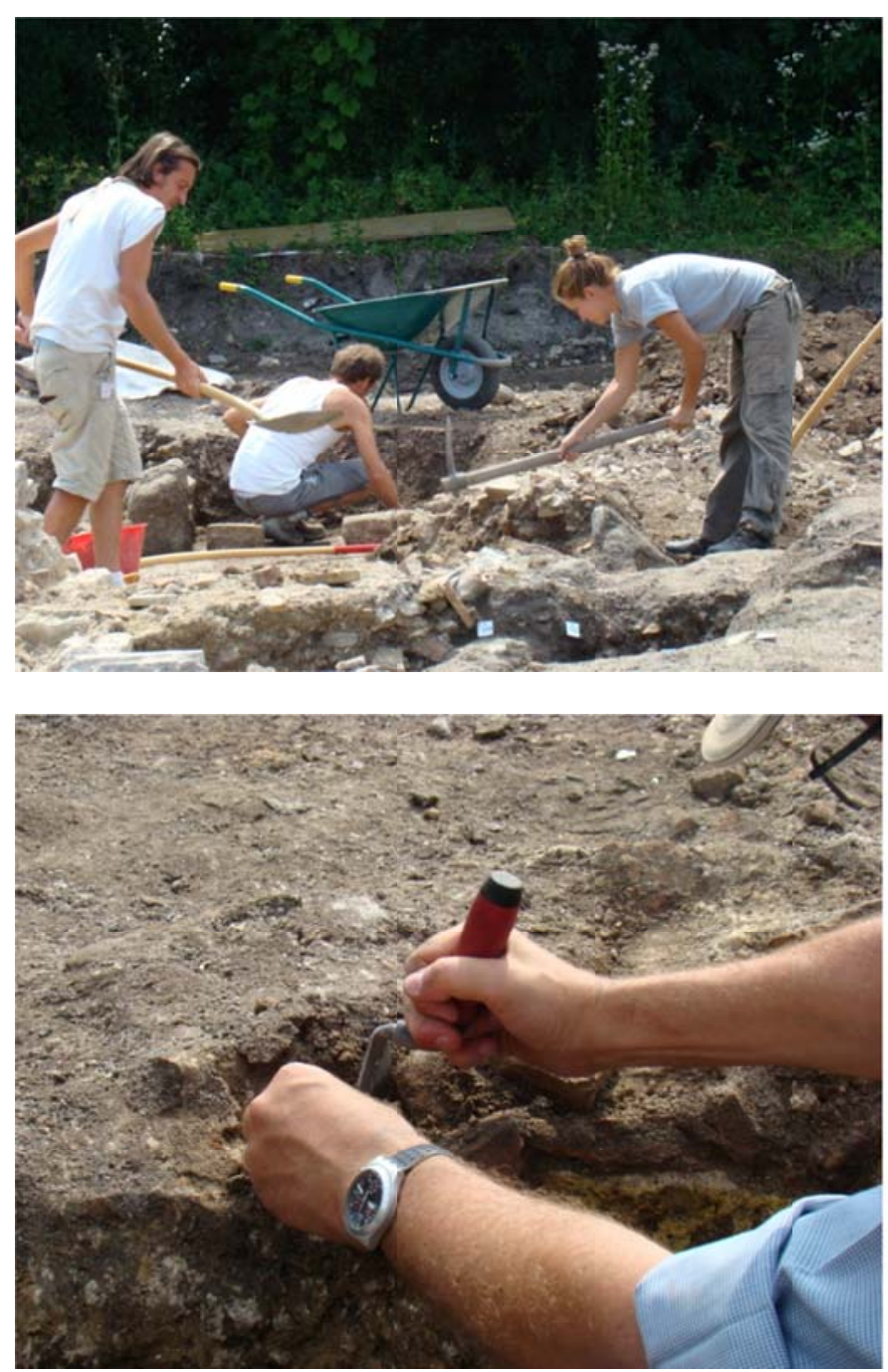

Figure 1. Pictures of Archaeologists Recovering a 200 ce House and the Techniques in Use. 
is ready to be used routinely. The major problem is the presence of moisture in the soil. Most resins and acrylics are incompatible with moisture. This consolidation needs to be done in situ so that the glass and soil can be removed as a unit. This allows the elemental profile to be measured in good relationship to the artifact. Additionally, the glass and soil are silica-based. The elements in the glass that are likely to be foreign to the soil are minor components in the glass. Therefore, tracking them in the soil is a difficult, but surmountable, analytical problem. Modern analytical techniques and instruments, such as laser ablation coupled to an inductively coupled mass spectrometer, make this more trackable. This technique has recently been used to solve a long-standing archaeological problem of the origin of the glass ingots in the shipwreck at Uluburun, Turkey.

\subsection{Conclusions}

There has been little dissolution testing of existing and simulated ancient glasses. Much of the work that has been done with ancient glasses has been characterization and conservation. More work has been done with natural glasses. However, as with the ancient glasses much of the work has been characterization with goal of understanding how the deposit evolved, what the contributions to the aqueous medium, and the alteration minerals. Recent work by the groups at CEA in France and at the University of Padova have provided a lot of information on the dissolution of the glass and its alteration. The CEA group interpret the data to suggest that a thin, 10-nm layer exists at the interface between the undissolved glass and the gel layer (A. Verney-Carron et al. 2009; Aurélie Verney-Carron et al. 2010). At $10 \mathrm{~nm}$, it is a layer that is nearly impossible to prove or disprove, but is suspect. The characterization of the alteration layers on the glasses from the Iulia Felix (Silvestri, Longinelli, and Molin 2010; Silvestri, Molin, and Salviulo 2005a) can be used to suggest that a 10-nm layer is not responsible for the behavior of glass in contact with water over nearly 2000 years of contact with sea water. More work in this area is needed. With the advent of new and very sensitive instrumentation, some of these open questions can be resolved by examining ancient glasses from various environments. Resolving the open questions with respect to ancient glasses results in resolution of the open questions with modern nuclear waste glasses and its long-term storage in near-surface or deep geologic repositories.

\subsection{References}

Anovitz, LM, DR Cole, and M Fayek. 2008, "Mechanisms of Rhyolitic Glass Hydration Below the Glass Transition." American Mineralogist 93:1166-78.

Anovitz, LM, DR Cole, and LR Riciputi. 2009, "Low-Temperature Isotopic Exchange in Obsidian: Implications for Diffusive Mechanisms." Geochimica Et Cosmochimica Acta 73:3795-806.

Anovitz, LM, LR Riciputi, DR Cole, MS Gruszklewicz, and JM Elam. 2006, "The Effect of Changes in Relative Humidity on the Hydration Rate of Pachuca Obsidian." Journal of Non-Crystalline Solids 352:5652-62.

Bajpai, RK and PK Narayan. 2005, "Natural Analogue Study of Resubelpara Group of Thermal Springs at Garo Hills, Meghalaya for Demonstration of Safe Geological Disposal of Nuclear Waste." Current Science 88:986-89. 
Bajpai, RK, PK Narayan, and RK Trivedi. 2006, "Radionuclide Transport Mechanism and in Situ Performance, Assessment of Waste Glasses, Metals and Clay Barriers of a Geological Repository: Possible Research Avenues at Puga Geothermal Field, Ladakth, Jammu and Kashmir." Journal of the Geological Society of India 68:984-88.

Barkatt, A, MS Boulos, W Sousanpour, MA Boroomand, PB Macedo, and JA Okeefe. 1984, "The Chemical Durability of Tektites - a Laboratory Study and Correlation with Long-Term Corrosion Behavior." Geochimica et Cosmochimica Acta 48:361-71.

Barkatt, A, EE Saad, R Adiga, W Sousanpour, A Barkatt, and MA Adel-Hadadi. 1989, "Leaching of Natural and Nuclear Waste Glasses in Sea Water." Applied Geochemistry 4:593-603.

Barkatt, A, EE Saad, R Adiga, W Sousanpour, A Barkatt, and S Alterescu. 1986. "Leaching of Microtektite Glass Compositions in Seawater." in Advances in Ceramics: Nuclear Waste Management II, DE Clark, WB White and AJ Machiels eds. The American Ceramic Society, Westerville, OH.

Barkatt, A, JC Sang, AN Thorpe, FE Senftle, IG Talmy, MK Norr, JJ Mazer, G Izett, and H Sigurdsson. 1994, "Surface Alteration an Physical-Properties of Glass from the Cretaceous-Tertiary Boundary." Geochimica et Cosmochimica Acta 58:2889-91.

Bates, JK, WL Ebert, JJ Mazer, JP Bradley, CR Bradley, and NL Dietz. 1991, "The Role of Surface Layers in Glass Leaching Performance." Materials Research Society Symposium Proceedings 212:77-87.

Bates, JK, LJ Jardine, and MJ Steindler. 1982, "Hydration Aging of Nuclear Waste Glass." Science 218: $51-54$.

Bates, JK and MJ Steindler. 1983, "Alteration of Nuclear Waste Glass by Hydration." in Scientific Basis for Nuclear Waste Management VI, ed. DG Brookins, Vol 15. North-Holland, New York, NY.

Benedetti, D, E Bontempi, R Bertoncello, B Dal Bianco, E Pantos, and LE Depero. 2007, "Study of Sea Water Influence on Chemical and Physical Degradation of Roman Glass." Nuovo Cimento Della Societa Italiana Di Fisica C-Geophysics and Space Physics 30:27-33.

Brill, RH. 1999, Chemical Analyses of Early Glasses. Technical, The Corning Museum of Glass, Corning, NY.

Carmona, N, M Oujja, E Rebollar, H Romich, and M Castillejo. 2005, "Analysis of Corroded Glasses by Laser Induced Breakdown Spectroscopy." Spectrochimica Acta Part B-Atomic Spectroscopy 60:1155-62.

Crovisier, JL, T Advocat, and JL Dussossoy. 2003, "Nature and Role of Natural Alteration Gels Formed on the Surface of Ancient Volcanic Glasses (Natural Analogs of Waste Containment Glasses)." Journal of Nuclear Materials 321:91-109.

Dal Bianco, B and R Bertoncello. 2008, "The Development of Growth Rings on Ancient Glass Surfaces: Description and Simulation of the Weathering." Journal of Non-Crystalline Solids 354:773-79.

Dal Bianco, B, R Bertoncello, L Milanese, and S Barison. 2005, "Glass Corrosion across the Alps: A Surface Study of Chemical Corrosion of Glasses Found in Marine and Ground Environments." Archaeometry 47:351-60. 
Dal Bianco, B, R Bertoncello, L Milanese, and S Barison. 2004, "Glasses on the Seabed: Surface Study of Chemical Corrosion in Sunken Roman Glasses." Journal of Non-Crystalline Solids 343:91-100.

Ewing, RC and G Roed. 1987, "Natural Analogues: Their Application to the Prediction of the Long-Term Behavior of Nuclear Waste Glasses." Materials Research Society Symposium Proceedings 84:67-83.

Frugier, P, S Gin, Y Minet, and T Chave. 2009, "SON68 Nuclear Glass Dissolution Kinetics: Current State of Knowledge and Basis of the New Graal Model." Geochimica et Cosmochimica Acta 73:A400A00.

Frugier, P, S Gin, Y Minet, T Chave, B Bonin, N Godon, JE Lartigue, P Jollivet, A Ayral, L De Windt, and G Santarini. 2008, "SON68 Nuclear Glass Dissolution Kinetics: Current State of Knowledge and Basis of the New Graal Model." Journal of Nuclear Materials 380:8-21.

Fuchs, DR, M Popall, H Romich, and H Schmidt. 1991. Preservation of Stained-Glass Windows - New Materials and Techniques. Science, Technology and European Cultural Heritage.

Ghiara, MR, E Franco, C Petti, D Stanzione, and GM Valentino. 1993, "Hydrothermal Interaction between Basaltic Glass, Deionized Water and Seawater." Chemical Geology 104:125-38.

Grambow, B and D Strachan. 1984, "Leach Testing of Waste Glasses under near-Saturation Conditions." Materials Research Society Symposium Proceedings 26:623-34.

Jantzen, CM. 1992, "Thermodynamic Approach to Glass Corrosion." in Corrosion of Glass, Ceramics, and Ceramic Superconductors, eds. DE Clark and BK Zoitos, pp. 153-215. Noyes Publications, Park Ridge, New Jersey.

Jantzen, CM and MJ Plodinec. 1984, "Thermodynamic Model of Natural, Medieval, and Nuclear Waste Glass Durability." Journal of Non-Crystalline Solids 67:207-23.

Jiřička, A, JD Vienna, P Hrma, and DM Strachan. 2001, "The Effect of Experimental Conditions and Evaluation Techniques on the Alteration of Low Activity Glasses by Vapor Hydration." Journal of NonCrystalline Solids 292:25-43.

Karkhanis, SN, RK Bajpai, and PK Narayan. 2006, "Shock Basaltic Glasses from Lonar Lake, Maharashtra: A Potential Natural Analogue of Nuclear Waste Glasses." Journal of the Geological Society of India 67:545-47.

Kruber, C, IH Thorseth, and RB Pedersen. 2008, "Seafloor Alteration of Basaltic Glass: Textures, Geochemistry, and Endolithic Microorganisms." Geochemistry Geophysics Geosystems 9.

Lamarche, PH, WA Lanford, and F Rauch. 1980, "Weathering of Tektites." Bulletin of the American Physical Society 25:600-00.

Longinelli, A, A Silvestri, G Molin, and G Salviulo. 2004, "1.8 Ka Old Glass from the Roman Ship Julia Felix: Glass-Water Oxygen Isotope Exchange." Chemical Geology 211:335-42.

Marini, F, L Dosztaly, G Don, and C Detre. 2000. Glassy Spatters in Mid-Triassic Limestones from Aszofo (Hungary): Anisian Tektites, Tethysian Volcanites, or Modern Slag-Wool Contaminants? Terrestrial and Cosmic Spherules, Proceedings. 
Mazer, JJ, JK Bates, JP Bradley, CR Bradley, and CM Stevenson. 1992, "Alteration of Tektite to Form Weathering Products." Nature 357:573-76.

Mazer, JJ, JK Bates, CM Stevenson, and CR Bradley. 1992, "Obsidians and Tektites: Natural Analogues for Water Diffusion in Nuclear Waste Glasses." Materials Research Society Symposium Proceedings 257:513-20.

Mees, F, E Cornelis, P Jacobs, MTD Carbo, and H Romich. 2009, "Microfocus X-Ray Computed Tomography Analysis of Corroded Glass Objects." Engineering Geology 103:93-99.

O'Keefe, JA. 1986. "The Corrosion of Tektite Glass." in Advances in Ceramics: Nuclear Waste Management II, DE Clark, WB White and AJ Machiels eds. The American Ceramic Society, Westerville, $\mathrm{OH}$.

Papelis, C, W Um, CE Russell, and JB Chapman. 2003, "Measuring the Specific Surface Area of Natural and Manmade Glasses: Effects of Formation Process, Morphology, and Particle Size." Colloids and Surfaces A-Physicochemical and Engineering Aspects 215:221-39.

Plodinec, MJ, CM Jantzen, and GG Wicks. 1984, "Stability of Radioactive Waste Glasses Assessed from Hydration Thermodynamics." Materials Research Society Symposium Proceedings 26:755-62.

Plodinec, MJ, CM Jantzen, and GG Wicks. 1984. Thermodynamic Approach to Prediction of the Stability of Proposed Radwaste Glasses. Advances in Ceramics 8, The American Ceramic Society, Columbus, Ohio.

Römich, H. 2007, "Archaeological Glasses: A Closer Look." Actualite Chimique:30-33.

Römich, H. 2006, "Glass and Ceramics." in Conservation Science - Heritage Materials, eds. E May and M Jones, pp. 159-83. The Royal Society of Chemistry Publishing, Cambridge, UK.

Römich, H. 2004, "Glass Sensors Measure Corrosiveness." Trac-Trends in Analytical Chemistry 23:XXI.

Römich, H. 1999, "Laboratory Experiments to Simulate Corrosion on Stained Glass Windows." in The Conservation of Glass and Ceramics, ed. N Tennent, pp. 57-65. James \& James, London, England.

Römich, H. 2000, "Simulation of Corrosion Phenomena of Historical Glasses on Model Glasses: An Update." Rivista della Staz. Sper. del Vetro 30:9-14.

Römich, H. 2003, "Studies of Ancient Glass and Their Application to Nuclear-Waste Management." Mrs Bulletin 28:500-04.

Römich, H, S Gerlach, P Mottner, F Mees, P Jacobs, D van Dyck, and TD Carbo. 2003, "Results from Burial Experiments with Simulated Medieval Glasses." in Scientific Basis for Nuclear Waste Management XXVI, eds. RJ Finch and DB Bullen, Vol 757, pp. 97-108.

Salviulo, G, A Silvestri, G Molin, and R Bertoncello. 2004, "An Archaeometric Study of the Bulk and Surface Weathering Characteristics of Early Medieval (5th-7th Century) Glass from the Po Valley, Northern Italy." Journal of Archaeological Science 31:295-306. 
Schatz, TR, AC Buechele, CF Mooers, R Wysoczanski, and IL Pegg. 2003, "Vapor Phase Hydration of Glasses in H2O and D2O." in Environmental Issues and Waste Management Technologies in the Ceramic and Nuclear Industries VIII, eds. SK Sundaram, DR Spearing and JD Vienna, Vol 143, pp. 253-62.

Shrivastava, JP, RK Bajpai, and N Rani. 2008, "A Review on Corrosion Mechanism in the Borosilicate Nuclear Waste Glass for Long-Term Performance Assessments in Geological Repository." Journal of the Geological Society of India 72:238-44.

Silvestri, A. 2008, "The Coloured Glass of Julia Felix." Journal of Archaeological Science 35:1489-501.

Silvestri, A, A Longinelli, and G Molin. 2010, "Delta O-18 Measurements of Archaeological Glass (Roman to Modern Age) and Raw Materials: Possible Interpretation." Journal of Archaeological Science 37:549-60.

Silvestri, A, G Molin, and G Salviulo. 2005a, "Archaeological Glass Alteration Products in Marine and Land-Based Environments: Morphological, Chemical and Microtextural Characterization." Journal of Non-Crystalline Solids 351:1338-49.

Silvestri, A, G Molin, and G Salviulo. 2008, "The Colourless Glass of Iulia Felix." Journal of Archaeological Science 35:331-41.

Silvestri, A, G Molin, and G Salviulo. 2005b, "Roman and Medieval Glass from the Italian Area: Bulk Characterization and Relationships with Production Technologies." Archaeometry 47:797-816.

Silvestri, A, G Molin, G Salviulo, and R Schievenin. 2006, "Sand for Roman Glass Production: An Experimental and Philological Study on Source of Supply." Archaeometry 48:415-32.

Strachan, DM. 2009, Some Thoughts on the Use of Ancient Glasses in Performance Assessment of Nuclear Waste Glass Disposal. Technical Rpt. PNNL-SA-69182 Pacific Northwest National Laboratory, Richland, WA.

Techer, I, T Advocat, J Lancelot, and JM Liotard. 2001, "Dissolution Kinetics of Basaltic Glasses: Control by Solution Chemistry and Protective Effect of the Alteration Film." Chemical Geology 176:23563.

Toniolo, A. 2008, "I Vetri Da Riciclare Del Relitto Grado 1." Aquileia Nostro, Anno LXXXIX.

Verney-Carron, A, S Gin, P Frugier, and G Libourel. 2009, "Coupled Chemistry-Transport Modeling of Glass Alteration Using Archaeological Fractured Samples." pp. A1379-A79.

Verney-Carron, A, S Gin, P Frugier, and G Libourel. 2010, "Long-Term Modeling of AlterationTransport Coupling: Application to a Fractured Roman Glass." Geochimica Et Cosmochimica Acta 74:2291-315.

Verney-Carron, A, S Gin, and F Libourel. 2007, "Use of Natural and Archaeological Analogs to Validate Long-Term Behaviour of HLW Glass in Geological Disposal Conditions." in Water-Rock Interaction, Vols 1 and 2, Proceedings, eds. TD Bullen and Y Wang, pp. 659-62.

Verney-Carron, A, S Gin, and G Libourel. 2008, "A Fractured Roman Glass Block Altered for 1800 Years in Seawater: Analogy with Nuclear Waste Glass in a Deep Geological Repository." Geochimica et Cosmochimica Acta 72:5372-85. 


\section{Distribution}

No. of

Copies

\# Name

Organization

Address

City, State and ZIP Code

\# Organization

Address

City, State and ZIP Code Name

Name

Name

Name

Name (\#)

\# Name

Organization

Address

City, State and ZIP Code
No. of

Copies

\# Foreign Distribution

\# Name

Organization

Address

Address line 2

COUNTRY

\# Local Distribution

Pacific Northwest National Laboratory

Name

Name

Mailstop

Mailstop

Name

Mailstop

Name

Mailstop

Name 




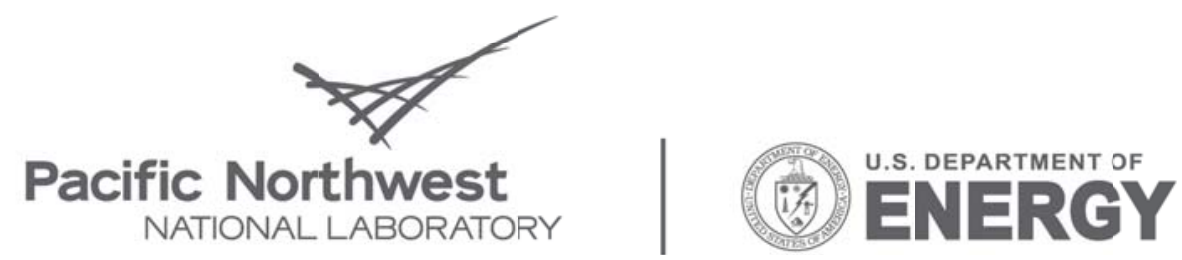

Proudly Operated by Battelle Since 1965

902 Battelle Boulevard

P.O. Box 999

Richland, WA 99352

1-888-375-PNNL (7665)

www.pnl.gov 